\title{
PENGARUH METODE LATIHAN DAN TINGKAT KONSENTRASI TERHADAP AKURASI TENDANGAN PINALTI
}

\author{
Rudy Saputra \\ STKIP Rosalia Lampung \\ rudy.s23@yahoo.com
}

\begin{abstract}
ABSTRAK
Penelitian ini bertujuan untuk mengetahui: 1) perbedaan antara pengaruh metode latihan menggunakan sasaran tetap dan menggunakan sasaran berubah terhadap akurasi tendangan pinalti, 2) perbedaan antara pengaruh tingkat konsentrasi tinggi dan konsentrasi rendah terhadap akurasi tendangan pinalti, 3) interaksi antara metode latihan dan tingkat konsentrasi terhadap akurasi tendangan pinalti.Penelitian ini menggunakanmetode eksperimen rancangan $2 \times 2$ pengambilan sampeldengan teknik purplosive samplingyaitu 24 pemain dari total populasi 33 pemain. Teknik analisis data digunakan uji anava dua jalurdan taraf signifikansi $a=0.05$, dan uji tukey. Hasil penelitian: 1) metode latihan menggunakan sasaran tetap memberikan pengaruh lebih baik terhadap akurasi tendangan pinalti dari padalatihan menggunakan sasaran berubah, 2) pemain dengan tingkat konsentrasi tinggi memberikan pengaruh lebih baik terhadap akurasi tendangan pinalti daripada pemain dengan tingkat konsentrasi rendah, 3) terdapat interaksi antara metode latihan dan tingkat konsentrasi terhadap akurasi tendangan pinalti.
\end{abstract}

Kata Kunci : Metode Latihan, Konsentrasi, Akurasi Tendangan

\section{ABSTRACT}

This study aimed to determine:1) the difference in influence of training method used goal fixed and training method used goal changed to the accuracy of penalty kicks, 2) thedifferences in the influence between the high and the low level of concentration to the accuracy of penalty kicks;3) the interaction of training methods and the level of concentration to theaccuracy penalty kicks. This study used experimental methods $2 x 2$ of factorial,sampling technique that used was purposive sampling that amounted 24players from 323 players. Data analysis technique in this study was analysis variant technique (anava) two lanes ofsignificance $a=0.05$ and the tukey test. The results of the study 1) the training method used goal fixed gave a better effect on the accuracy penalty kicks than exercises method used goal changed; 2) players who had high level of concentration gave a better effect on the accuracy penalty kicks than players who had lower level of concentration; 3) there was an interaction between training method and the level of concentrationplayers on the accuracy penalty kicks

Key Words: Training Method, Cocentration, Kicks Accuracy

Dipublikasikan Oleh :

UPT Publikasi dan Pengelolaan Jurnal

Universitas Islam Kalimantan Muhammad Arsyad Al-Banjari Banjarmasin 


\section{PENDAHULUAN}

Teknik dasar yang penting dalam sepakbola adalah menendang bola. Menendang bola adalah bagian yang terpenting, seorang pemain sepakbola yang tidak dapat menendang bola dengan baik, tidak mungkin menjadi pemain yang baik hampir setiap kesebelasan yang mendapat kemenangan (membuat gol) sebagian besar dihasilkan dari tendangan yang baik. Akurasi merupakan usaha yang dilakukan untuk mencapai tujuan tanpa melakukan kesalahan. Usaha yang dimaksud dalam penelitian ini adalah melakukan tendangan pinalti. Pengendalian gerakan yang dimaksud adalah kakidengan bola, dan sasarannya adalah gawang lawan.Oleh karena itu,keahlian dan keakurasian menyerangkan bola ke gawang sangat penting untukmencetak angka.

Hasil wawancara pada tanggal 16 januari 2017 dengan pelatih dan pemain yang pernah gagal melakukan tendangan pinalti diketahui penurunan konsentrasi pada pemain sepak bola tersebut pada saat berlatih maupun bertanding disebabkan karena banyak faktor seperti faktor kelelahan, sorakan penonton dan keadaan psikis pemain yang tidak seimbang. Faktor-faktor tersebut yang mengakibatkan konsentrasi atlet menurun dalam melakukan tendangan pinalti,sehingga tingkat keberhasilan dalam melakukan tendangan penalti kurang maksimal.

Drama pada babak adu pinalti seolah menjadi momok bagi tim Sepakbola Universitas Lampung, terlihat dari tahun 2013 - 2015 dalam 3 final kejuaraan, tim Sepakbola Universitas Lampung gagal meraih kemenangan karena babak adu pinalti. Babak adu pinalti bukan hanya soal pengalaman seseorang yang terbiasa mencetak gol pinalti saja, melainkan juga tentang akurasi tendangan dankesiapan diri dari seorang pemain tersebut untuk melakukannya.(Pelatih Sepakbola Universitas Lampung, 2016). Dalam kompetisi sepakbola bahwa kemenangan merupakan tujuan yang utama, dan kemenangan ditentukan oleh keberhasilan pemain memasukan bola kedalam gawang. Oleh karena seorang pemain dikatakan baik bilapemain menguasai teknik dasar dengan benar (Dinata, 2013) . Konsentrasi merupakan kemampuan olahragawan dalam memelihara fokus perhatiannya dalam lingkungan pertandingan yang relevan (Weinberg, R.S. dan Gould, 2007). Konsentrasi termasuk aspek mental dalam olahraga dan memegang peranan penting, dengan berkurangnya atau terganggunya konsentrasi atlet pada saat latihan, apalagi pertandingan, maka akan timbul berbagai masalah serta hasil yang tidak optimal seperti tendangan pinalti yang gagal.

Keterampilan menendang pinalti, konsentrasi sangat dibutuhkan.Pemain harus berkonsentrasi melihat posisi penjaga gawang dan perkenaan bola dengan punggung kaki atau kaki bagian dalam dan arahnya tepat. Situasi di atas sangat sulit jika pemain tidak memiliki daya konsentrasi yang baik, karena perhatiannya terbelah dengan adanya lawan, penjaga gawang yang melakukan gerakan dan harus mengarahkan bola ke gawang tanpa bisa dihalau penjaga gawang. Pemain sering gagal melakukan tendangan pinalti karena tingkat perhatian dan konsentrasi atlet menurun atau terganggu bila ada beberapa rangsang yang muncul bersamaan (Sukadiyanto, 2006)

(Lutan, 1988) menjelaskan "salah satu metode terbaik untuk meningkatkan keterampilan yakni secara langsung mempelajari kegiatan yang dimaksud melalui kegiatan praktek secara berulang-ulang dengan tekanan pada pembiasaan". Selanjutnya (Rahyubi, 2011) menjelaskan "bahwa upaya penguasaan keterampilan tidak hanya difokuskan pada pembelajaran geraknya saja, melainkan disadari perlunya menyisihkan waktu untuk latihan mental atau yang disebut latihan nir-gerak atau nir-motorik seperti latihan imagery. Atas dasar uraian dan penjelasan dalam latar belakang masalah di atas, maka penulis tertarik untuk mengadakan penelitian yang berjudul, " Pengaruh Metode Latihan dan Tingkat Konsentrasi Terhadap Akurasi Tendangan Pinalti pada UKM Sepakbola Universitas Lampung". Tujuan penelitian ini adalah untuk menganalisa dan menguji perbedaan pengaruh antara metode latihan terhadap akurasi tendangan pinalti pada pemain sepakbola Universitas Lampung.

\section{METODE}

Desain penelitian yang digunakan dalam penelitian ini adalah menggunakan desain faktorial. Data dalam desain faktorial ini, perlakuan akan disusun sedemikian rupa sehingga setiap individu dapat menjadi subjek secara bersamaan, dalam faktor yang berbeda dan dalam setiap faktornya terdiri dari beberapa level. Desain faktorial merupakan bagian dari penelitian eksperimen yang terdiri dari dua atau lebih variabel independen yang dikombinasikan. Desain penelitian ini menggunakan rancangan faktorial $2 \times 2$, dengan menggunakan tes awal (pretest) dan tes akhir (posttest).

Proses penelitian, tes pertama yang dilakukan adalah Tes tingkat konsentrasi yang digunakan adalah Constant Alternative Scales, yang di gunakan untuk membagi kelompok dan menentukan kecepatan kategori tinggi dan kategori rendah. Setelah itu peneliti melakukan Pre Test, tes akurasi tendangan pinalti menggunakan instrument gawang yang diberikan. Adapun teknik pengambilan kelompok yang digunakan adalah dengan membagi hasil tes tingkat akurasi tendangan pinalti dalam 2 kategori kelompok, yaitu tinggi dan rendah. Langkah berikutnya adalah membagi kelompok kategori tinggi dan rendah menjadi 2 sub kelompok yang di 
lakukan dengan ordinary pairing (A-B-B-A) penggunaan cara ini dapat 2 sub yang seimbang atau menyetarakan kemampuan sampel tiap kelompok.

Uji Normalitas menggunakan Kolmogrov - Smirnof dan uji homogenitas menggunakan Leavene's Test atau uji $\mathrm{F}$ pada taraf signifikan 5\%. Sampel berdistribusi normal dan homogen apabila nilai sinifikansi lebih besar dari $\alpha(\operatorname{Sig}>5 \%)$. Analisis data menggunakan Anava SPSS 16,0 pada taraf signifikan 0,05.

\section{HASIL DAN PEMBAHASAN}

Data yang diperoleh melalui penggunaan instrumen menghasilkan data awal berupa pre-tes dan data akhir berupa pos-tes, data tersebut selanjutnya dilakukan uji normalitas dengan menggunakan Kolmogorov Smirnovpada taraf signifikan 5\% $(a=0,05)$ dan ketentuan bahwa data berdistribusi normal apabila nilai signifikansi >0,05. Dalam hal ini peneliti menggunakan program SPSS 16.0 untuk melakukan uji Kolmogorov Smirnov, berikut hasil perhitungannya :

Tabel 1. Hasil Uji Normalitas Data

\begin{tabular}{cccc}
\hline Data & Kolomoorov Smirnov Z & Sign & Keterangan \\
& & & \\
Pre-tes & 1,185 & $>0,05$ & Normal \\
Pos-tes & 0,997 & $>0,05$ & Normal \\
\hline
\end{tabular}

Uji homogenitas pada penelitian ini dilakukan dengan uji varians (Ms. Excel 2007) dan uji Levene (SPSS 16.0). Uji homogenitas dilakukan untuk menguji kesejenisan data yang bersumber dari data pre-tes dan pos-tes. Berikut hasil uji analisis homogenitas :

Tabel 2. Hasil Uji Homogenitas Data

\begin{tabular}{cccc}
\hline $\mathbf{F}$ & df1 & df2 & Sig. \\
2,998 & 3 & 20 & 0,055 \\
\hline
\end{tabular}

Dari hasil uji homogenitas diperoleh nilai signifikansi 0,055>0,05 yang berarti bahwa varians data antara kelompok tidak berbeda nyata atau bersifat homogen. Pengujian hipotesis penelitian dilakukan berdasarkan hasil analisis data dan interaksi analisis varians. Untuk mengetahui perbedaan hasil pengujian hipotesis maka peneliti melakukan uji Anava dua jalur (SPSS 16.0), hasil perhitungan Anava menunjukkan adanya perbedaan yang signifikan.

Berdasarkan hasil analisis data di atas dapat dilakukan pengujian hipotesissebagai berikut :

1. Terdapat perbedaan pengaruh antara metode latihan menggunakan sasaran tetap dan metode latihan menggunakan sasaran berubah terhadap akurasi tendangan pinalti.

Hipotesis 1 yang menyatakan terdapat perbedaan pengaruh antara metode latihan menggunakan sasaran tetap dan metode latihan menggunakan sasaran berubah terhadap akurasi tendangan pinaltipadapemain sepakbola Universitas Lampung diuji menggunakan uji anava dan diperoleh $F_{\text {hitung }}=6,591$ dengan nilai signifikansi 0,005 . Hasil perhitungan ini kemudian dikonsultasikan dengan tabel $\mathrm{F}$ taraf signifikansi 0,05 diperoleh $F_{\text {tabel }}=3,10$ karena $F_{\text {hitung }}>F_{\text {tabel }}$ atau 6,591> 3,10 dan nilai signifikansi 0,018<0,05 maka Ha yang berbunyi : "terdapat perbedaan pengaruh antara metode latihan menggunakan sasaran tetap dan metode latihan menggunakan sasaran berubah terhadap akurasi tendangan pinalti”. diterima. Dilihat dari hasil nilai rata-rata postes menunjukan metode latihan menggunakan sasaran tetap memberikan pengaruh yang lebih baik terhadap akurasi tendangan pinalti pemain Sepakbola Universitas Lampung dibandingkan metode latihan menggunakan sasaran berubah.

2. Terdapat perbedaan pengaruh bagi pemain yang memiliki tingkat konsentrasi tinggi dan rendah terhadap akurasi tendangan pinalti.

Hipotesis 2 yang menyatakan terdapat perbedaan pengaruh antara pemain yang memiliki tingkat konsentrasi tinggi dan rendah terhadap akurasi tendangan pinalti, pemain sepakbola Universitas Lampung diuji menggunakan uji anava dan diperoleh $\mathrm{F}_{\text {hitung }}=5,768$ dengan nilai signifikansi 0,026. Hasil perhitungan ini kemudian dikonsultasikan dengan tabel $\mathrm{F}$ taraf signifikansi 0,05 diperoleh $\mathrm{F}_{\text {tabel }}=3,10$ karena $\mathrm{F}_{\text {hitung }}>\mathrm{F}_{\text {tabel }}$ atau 5,768> 3,10 dan nilai signifikansi 0,026 <0,05 maka Ha yang berbunyi : “Terdapat perbedaan pengaruh antara pemain yang memiliki tingkat konsentrasi tinggi dan rendah terhadap akurasi tendangan pinalti”. diterima.

Dipublikasikan Oleh :

UPT Publikasi dan Pengelolaan Jurnal

Universitas Islam Kalimantan Muhammad Arsyad Al-Banjari Banjarmasin 
Dengan demikian pemain yang memiliki tingkat konsentrasi tinggi berperan terhadap akurasi tendangan pinaltidibandingkan dengan pemain yang memiliki tingkat konsentrasi rendah.

3. Terdapat interaksi antara metode latihan dan tingkat konsentrasi terhadap akurasi tendangan pinalti.

Untuk menguji hipotesis 3 yaitu terdapat interaksi antara metode latihan dan tingkat konsentrasi terhadap akurasi tendangan pinalti pemain sepakbola Universitas Lampung digunakan uji anava, diperoleh $F_{\text {hitung }}=5,000$ dengan nilai signifikansi 0,037. Hasil perhitungan ini kemudian dikonsultasikan dengan tabel $\mathrm{F}$ taraf signifikansi 0,05 diperoleh $F_{\text {tabel }}=3,10$, karena $F_{\text {hitung }}>F_{\text {tabel }}$ atau 5,000 >3,10 dan nilai signifikansi $0,037<0,05$ maka Ha yang berbunyi : "Terdapat interaksi antara metode latihan dan tingkat kosentrasi terhadap akurasi tendangan pinalti ". diterima. Dengan demikian terdapat interaksi antara metode latihan dan tingkat konsentrasi terhadap peningkatan akurasi tendangan pinalti pada pemain sepakbola Universitas Lampung.

Selanjutnya data dilakukan analisis lanjut dengan uji tukey untuk mengetahui sejauh mana perbedaan interaksi masing-masing kelompok perlakuan. Berikut hasil perhitungan pada tabel :

Tabel 3. Perbedaan Interaksi Masing-Masing Kelompok Perlakuan Menggunakan Uji Tukey

\begin{tabular}{cccc}
\hline Kelompok yang Dibandingkan & $\mathbf{Q}_{\text {hit }}$ & $\mathbf{Q}_{\text {tabel }}$ & Keterangan \\
A1B1 $><$ A1B2 & 0,18 & 3,90 & Tidak Berbeda \\
A2B1 $><$ A2B2 & 5,11 & 3,90 & Berbeda \\
A1B1 $><$ A2B1 & 0,36 & 3,90 & Tidak Berbeda \\
A1B2 $><$ A2B2 & 5,29 & 3,90 & Berbeda \\
A1B1 $><$ A2B2 & 5,47 & 3,90 & Berbeda \\
A1B2 $><$ A2B1 & 0,18 & 3,90 & Tidak Berbeda \\
\hline
\end{tabular}

Tabel di atas dari uji tukey menunjukan bahwa ada 3 kelompok memiliki perbedaan dan 3 kelompok tidak memiliki perbedaan.Kelompok-kelompok yang memiliki perbedaan, yaitu kelompok A2B1 dengan A2B2, A1B2 dengan A2B2 dan A1B1 dengan A2B2.Sedangkan kelompok - kelompok yang tidak memiliki perbedaan yaitu kelompok A1B1 dengan A1B2, A1B1 dengan A2B1 dan A1B2 dengan A2B2.Perbedaan tersebut diketahui dari skor $\mathrm{q}_{\text {hitung }}$ yang lebih besar daripada $\mathrm{q}_{\text {tabel. }}$. Dimana $\mathrm{q}_{\text {hitung }}$ untuk kelompok A1B1 dengan A1B2 yaitu 0,18< $\mathrm{q}_{\text {tabel }} 3,90$, $\mathrm{q}_{\text {hitung }}$ untuk kelompok A2B1 dengan A2B2 yaitu 5,11> $\mathrm{q}_{\text {tabel }} 3,90$, $\mathrm{q}_{\text {hitung }}$ untuk kelompok A1B1 dengan $A 2 B 1$ yaitu $0,36<\mathrm{q}_{\text {tabel }} 3,90$, $\mathrm{q}_{\text {hitung }}$ untuk kelompok A1B2 dengan A2B2 yaitu 5,29> $\mathrm{q}_{\text {tabel }} 3,90$, dan $\mathrm{q}_{\text {hitung }}$ untuk kelompok A1B1 dengan A2B2 yaitu 5,47> $\mathrm{q}_{\text {tabel }} 3,90$, sedangkan $\mathrm{q}_{\text {hitung }}$ untuk kelompok A1B2 dengan A2B1, yaitu $0,18<\mathrm{q}_{\text {tebel }} 3,90$.

Latihan tendangan pinalti menggunakan sasaran tetap yaitu menendang bola dari titik penalti dimana sasarannya satu arah saja. Untuk melakukan latihan tendangan ini bola yang ditendang diarahkan pada salah satu daerah sasaran yang telah diberi nomor. Pemain diberi pilihan untuk menentukan sasaran sehingga pada latihan menggunakan sasaran tetap ini dapat mendorong pemain untuk melakukan penekanan ketepatan dalam mengarahkan bola ke satu sasaran saja, sehingga latihan lebih terfokus dan juga bisa memberikan rangsangansecara otomatisasi pada satu sasaran.

Sedangkan latihan tendangan pinalti menggunakan sasaran berubah yaitu menendang bola dari titik penalti dengan beberapa sasaran. Sasaran menggunakan gawang yang dibagi menjadi tujuh daerah sasaran. Dalam latihan ini pemain diberi kebebasan untuk mengarahkan bola ke daerah sasaran, namun arah sasarannya harus selalu berubah, pemain dituntut adanya pengkoordinasian untuk mengarah pada sasaran harus lebih teliti dibandingkan dengan sasaran tetap karena menggunakan berbagai arah sasaran dan penekanan ketepatan dalam mengarahkan bola lebih dari satu sasaran, sehingga latihan kurang terfokus (Pranoto, 2007).

Tendangan ke daerah sudut gawang adalah yang paling sulit untuk dijangkau penjaga gawang.Tendangan kearah sudut gawahmenjadi strategi terbaik tendangan pinalti mungkin untuk bertujuan untuk dua sudut atas. Latihan yang tepat akan membantu dalam mengurangi tingkat kegagalan tendangan tersebut (Bar-Eli, 2009)

Dengan demikian suatu metode latihan dalam melatih sangat perlu, karena didalamnya terdiri dari seperangkat usaha mengelola pengalaman latihan dan prilaku para pemain dengan maksud agar pemain aktif dalam melaksanakan tugas - tugas latihan salah satunya adalah latihan menendang menggunakan imagery untuk meningkatkan akurasi tendangan ke gawang pemain (Chandra, 2015)

Berdasarkan hal di atas diperoleh kesimpulan bahwa terdapat pengaruh dan perbedaan peningkatan akurasi tendangan pinalti dari metode latihan yang diterapkan antara yang menggunakan sasaran tetap dan sasaran berubah yang memiliki karakter, ciri, dan prosesyang berbeda dari kedua metode latihan menggunakan

Dipublikasikan Oleh :

UPT Publikasi dan Pengelolaan Jurnal

Universitas Islam Kalimantan Muhammad Arsyad Al-Banjari Banjarmasin 
sasaran tetap dan sasaran berubah. Oleh karena itu metode latihan menggunakan sasaran tetap dan sasaran berubah dapat diterapkan dalam program latihan sepak bola, karena memiliki peningkatan akurasi tendangan pinaltikhususnya latihan tendangan pinalti.

Kemampuan dasar penendang adalah indikator yang dapat diandalkan tingkat keberhasilannya, tingkat spesialisasi penendang meningkat dengan adanya kemampuan dasar yang baik, dan penendang yang menggunakan kaki kiri yang lebih sedikit dalam total populasi memiliki tingkat keberhasilan yang lebih tinggi dibandingkan penendang yang menggunakan kaki kanan.

Berdasarkan peningkatan akurasi tendangan yang diperoleh bahwa kelompok pemain yang memiliki tingkat konsentrasi tinggi lebih baik daripada kelompok pemain yang memiliki tingkat konsentrasi rendah, karena pada kelompok pemain yang memiliki tingkat konsentrasi tinggi memiliki kemampuan untuk memfokuskan diri terhadap sesuatu, cepat dan tepat dibandingkan dengan kelompok pemain yang memiliki tingkat konsentrasi rendah.

Konsentrasi adalah salah satu aspek mental yang dibutuhkan seseorang pemain sepak bola, kemampuan untuk melakukan konsentrasi selama pertandingan juga sangat penting karena dalam proses jalannya pertandingan sangat menguras kemampuan berpikir pemain dalam memenangkan sebuah pertandingan apabila konsentrasi dan ketepatannya bagus khususnya dalam halini menendang bola ketika terjadi tendangan pinalti dalam sebuah pertandingan.

Konsentrasi merupakan bagian dari psikologi yang mendukung pencapaian prestasi atlet khususnya dalam bidang olahraga. "Dalam olahraga terdapat sebuah faktor psikis yang dapat menunjang ataupun menghambat prestasi,faktor tersebut adalah perhatian dan konsentrasi”.Gunarsa (2008:87). Sedangkan menurut (Maksum, 2012), Terganggunya konsentrasi dapat berakibat pada penurunan performa atlet dilapangan. Misalnya berkurangnya akurasi lemparan, pukulan, tendangan atau tembakan sehingga tidak mengenai sasaran yang dituju. Dalam permainan sepakbola salahsatu teknik yang membutuhkan konsentrasi adalah ketepatan menendang bola (tendangan pinalti).

Gerakan yang dilakukan kiper akan mengganggu penendang dan akan mempengaruhi akurasi tendangan pinalti. Tembakan lebih terpusat, yaitu, condong ke kiper. Latihan yang harus diberikan pada penendang adalah penentuan arah bola dan tingkat keakurasian. Hasil dari penelitian ini menyimpulkan gerakan gangguan yang dilakukan oleh kiper dapat mempengaruhi penendang secara psikologis dan penendang harus mengarahkan tendangan pinalti dengan akurat (Navarro, 2013) Berdasarkan hal di atas dapat disimpulkan bahwa pemain dengan tingkat konsentrasi terhadap akurasi tendangan pinalti terdapat perbedaan yang signifikan yaitu pemain dengan tingkat konsentrasi tinggi akan memiliki keakurasian tendangan pinalti yang lebih baik dibandingkan dengan pemain yang memiliki tingkat konsentrasi rendah.Hal tersebut dikarenakan pemain dengan tingkat konsentrasi rendah akan lebih mengalami kesulitan dalam memusatkan perhatian dan pengkoordinasian gerakan dibandingkan dengan pemain yang memiliki tingkat konsentrasi yang tinggi. Menunjukkan bahwa semakin tinggi tingkat konsentrasi, maka pemain akan berusaha meraih skor yang maksimal pada saat bertanding padapermainan sepakbola (Anindhika, 2016)

Hasil yang berkaitan dengan pengujian hipotesis interaksi, membuktikan bahwa terdapat interaksi antara metode latihan dengan tingkat konsentrasi dalam pengaruhnya terhadap akurasi tendangan pinalti, atau dengan kata lain hipotesis penelitian yang diajukan teruji kebenarannya. Hal ini menunjukan bahwa untuk meningkatkan akurasi tendangan pinalti tidak hanya dengan menggunakan metode latihan saja, tetapi juga ditentukan oleh bagaimana kemampuan tingkat konsentrasiyang dimiliki pemain. Walaupun pelatih telah menggunakan metode latihan dengan baik tanpa didukung oleh tingkat konsentrasi yang tinggi, maka hal ini akan menyebabkan tidak tercapainya tujuan dari latihan, sehingga proses latihan tidak dapat diserap dengan sempurna oleh pemain. Ini menunjukan bahwa untuk meningkatkan akurasi tendangan pinalti, pelatih harus bisa memlilih metode latihan yang sesuai dan juga mempertimbangkan tingkat konsentrasi pemain.

Berdasarkan pembahasan tersebut, terdapat interaksi antara tingkat konsentrasi pemain dengan metode latihan yang digunakan terhadap akurasi tendngan pinalti. Terjadi interaksi antara metode latihan dengan tingkat konsentrasi sebagimana dijelaskan di atas dapat digambarkan melalui perbandingan rata-rata skor akurasi tendangan pinalti antara kelompok pemain dengan kategori tinggi dan rendah dengan perlakuan yang sama.

Akurasi tendangan pinalti di pengaruhi oleh kemampuan tingkat konsentrasi.Agar proseslatihan yang dilakukan mencapai hasil yang maksimal maka perlu diterapkan metode latihan yang tepat.Dengan demikian tingkat konsentrasi sangat penting untuk meningkatkan kemampuan akurasi tendangan pinalti. Seperti yang diketahui sebelumnya, metode latihan akan dipengaruhi oleh beberapa komponen untuk pencapaian tujuan yang efektif dan maksimal. Hal ini akan berkaitan dengan efektifitas hasil akurasi tendangan pinalti.

\section{PENUTUP}

Dipublikasikan Oleh : 
Hasil studi literature yang sudah dijelaskan diatas memiliki banyak manfaat mengenai pertimbangan berdasarakan landasan dan teori-teori yang telah dikemukakan bahwa 1)Secara umum dapat dikatakan bahwa metode latihan dan tingkat konsentrasi merupakan unsur yang mempengaruhi akurasi tendangan penalti. 2) Metode latihan menggunakan sasaran tetapmemberikan hasil keakurasian tendangan penalti yang lebih baik dari pada metode latihan menggunakan sasaran berubah, karena pemain menjadi lebih fokus dan dapat mendorong pemain untuk melakukan penekanan ketepatan dalam mengarahkan bola ke satu sasaran saja, sehingga latihan lebih terfokus dan juga bisa memberikan rangsangan secara otomatisasi pada satu sasaran. 3) Peningkatan hasil akurasi tendangan penaltidengan menerapkan metode latihan menggunakan sasaran tetap dan sasaran berubahpada pemain, juga dipengharuhi oleh tingkat konsentrasi. Tingkat konsentrasi berhubungan dengan kemampuan untuk memfokuskan diri terhadap sesuatu, cepat dan tepat.

Kesimpulan

Berdasarkan hasil penelitian dan pembahasan tentang penerapan metode latihan dan tingkat konsentrasi terhadap akurasi tendangan pinalti pada pemain Sepak Bola Universitas Lampung, maka dapat diambil kesimpulan sebagai berikut.Terdapat perbedaan pengaruh antara metode latihan menggunakan sasaran tetap dan metode latihan menggunakan sasaran berubah terhadap akurasi tendangan pinalti.Metode latihan menggunakan sasaran tetap memberikan pengaruh yang lebih baik daripada menggunakan metode latihan menggunakan sasaran berubah.Terdapat perbedaan pengaruh antara pemain yang memiliki tingkat konsentrasi tinggi dan rendah terhadap akurasi tendangan pinalti.Pemain yang memiliki tingkat konsentrasi tinggi lebih baik daripada pemain yang memiliki tingkat konsentrasi rendah.Terdapat interaksi antara metode latihan dan tingkat konsentrasi pemain terhadap akurasi tendangan pinalti.

\section{REFERENSI}

Anindhika, A. B. (2016). Kontribusi Konsentrasi Terhadap Ketepatan Passing Lambung Saat Melakukan Tendangan Sudut Pada Pemain SSB Mitra Surabaya U-14. Jurnal Kesehatan Olahraga, 5(2), 35-40.

Bar-Eli, M. (2009). "Penalty kicks in soccer: an empirical analysis of shooting strategiesand goalkeepers' preferences". Wingate Institute for Physical Education and Sports, Israel, 10(2).

Chandra, A. (2015). "Pengaruh Latihan Menendang Menggunakan Imageri Terhadap Akurasi Tendangan Ke Gawang”. Skripsi. Universitas Islam Riau.

Dinata, M. (2013). Dasar-Dasar Sepak Bola. Cerdas Jaya.

Lutan, R. (1988). Belajar Keterampilan Motorik, Pengantar Teori dan Metode. Depdikbud. Dirjen. Pendidikan Tinggi. P2LPTK.

Maksum, A. (2012). Metodologi Penelitian dalam Olahraga. Unesa University Press.

Navarro, M. (2013). “The Mere Presence Of A Goalkeeper Affects The Accuracy Of Penalty Kicks.” Journal of Sports Sciences, 9(1), 921-929.

Pranoto. (2007). “Perbedaan Hasil Latihan Menendang Bola dengan Sasaran Tetap dan Sasaran Berpindah Terhadap Ketepatan Tembakan Kegawang pada PS.Putra Pandawa Slawi Kab. Tegal Tahun 2007”. Skripsi. Unnes.

Rahyubi, H. (2011). Teori-Teori Belajar dan Aplikasi Pembelajaran Motorik Deskripsi dan Tinjauan Kritis. Nusa Media.

Sukadiyanto. (2006). Konsentrasi dalam olahraga. Majalah Ilmiah Olahraga FIK UNY, 12 April.

Weinberg, R.S. dan Gould, D. (2007). Foundations of Sport \& Exercise Psychology. Human Kinetics.

Dipublikasikan Oleh :

UPT Publikasi dan Pengelolaan Jurnal

Universitas Islam Kalimantan Muhammad Arsyad Al-Banjari Banjarmasin 